Volume 16, Number 1, Juni 2019

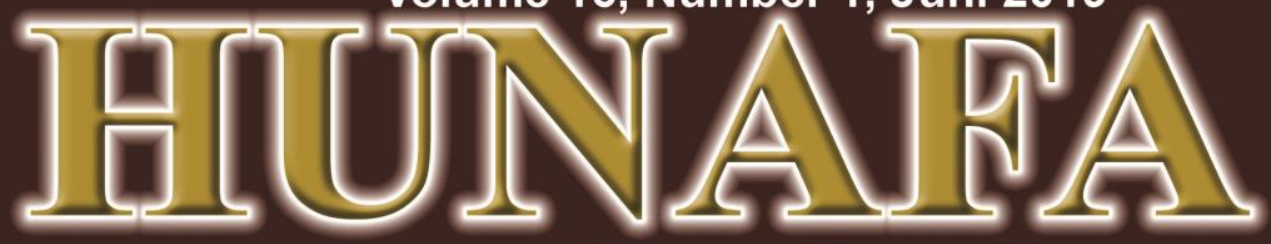

Jurimal Stradial Islamilka

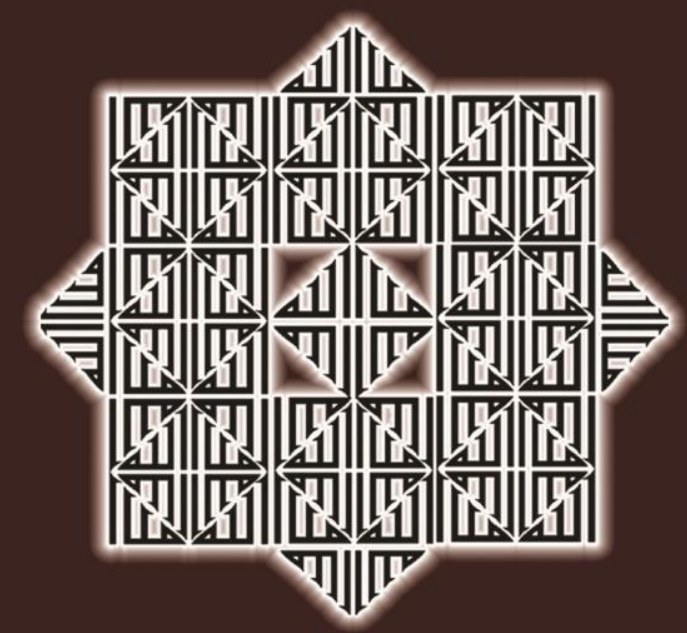

ALKHAIRAAT POLITICAL CHARISMA Syamsuri

IRAN REVOLUTION, ECONOMIC STRUGGLE AND INDEPENDENCE UNDER PRESSURE Meirizon Alizar Ali

\author{
MARKETING PERFORMANCE DETERMINANT \\ OF HALAL PRODUCTS IN INDONESIA \\ Confirmatory Factor Analysis Approach \\ Aan Nasrullah
}

State lnstitute for lsiamic Studies (ILAIN) Palu central Sulawesi

\begin{tabular}{|c|c|c|c|c|c|}
\hline $\begin{array}{c}\text { HUNAFA } \\
\text { JSI }\end{array}$ & $\begin{array}{c}\text { Volume } \\
16\end{array}$ & $\begin{array}{c}\text { Number } \\
1\end{array}$ & $\begin{array}{c}\text { Page } \\
1-153\end{array}$ & $\begin{array}{c}\text { Palu } \\
\text { Juni } 2019\end{array}$ & $\begin{array}{c}\text { ISSN } \\
\text { 141-125X }\end{array}$ \\
\hline
\end{tabular}




\section{HUNAFA}

Jurnal Studia Islamika

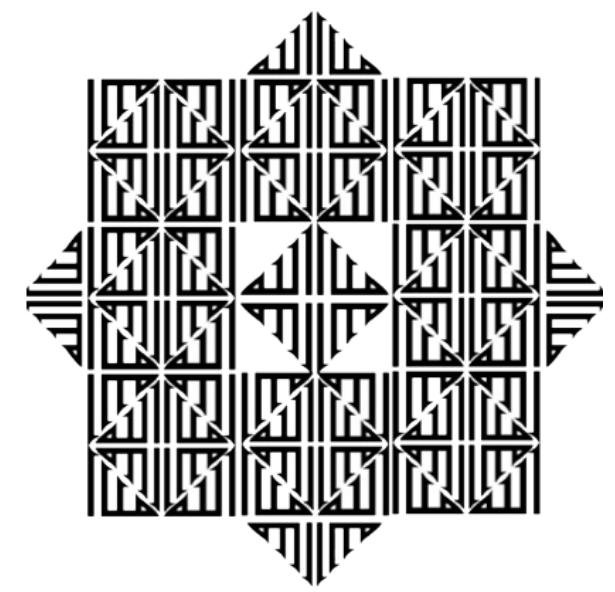

Published by:

State Islamic Institute (IAIN) Palu

Central Sulawesi 


\section{HUNAFA}

Jurnal Studia Islamika

HUNAFA: Jurnal Studia Islamika is an Islamic studies journal dedicated to publishing scholarly articles on all aspects of Islam and the Muslim peoples and religious studies. Available in print and online and published twice a year, the journal aims to become one of the leading platforms in Indonesia for new findings and discussions of all fields of Islamic studies. This journal invites scholars, researchers, and students to contribute the result of their studies and researches in the areas related to Islam and Muslim society which covers textual and fieldwork investigation with various perspectives of law, education, quranic studies, economiy, philosophy, mysticism, theology, sociology, and others.

\section{CAll rights reserved}

No part of this publication may be reproduced in any form without written permission from HUNAFA, to whom all requests to reproduce copyright material should be directed. HUNAFA grants authorization for individuals to photocopy copyright material for private research use. This authorization does not extend to any other kind of copying, by any means, in any form, and for any purposes other than private research.

\section{Open Acces Journal Information}

The journal provides immediate open access to its content on the principle that making research freely available to the public supports a greater global exchange of knowledge. The journal offers full access contents at http://jurnalhunafa.org.

\section{Printed Journal Subscription Information}

Institution Rp 100.000,00 /issue; Rp 1.100.000,00/year

Individual: Rp. 60.000,00/issue; Rp. 600.000,00/year

Outside Indonesia (individual or institution) \$60/month; \$600/year

For detail information of printed journal subscription, feel free to contact the journal manager at hunafajournal@gmail.com.

\section{Mailing Address}

HUNAFA: Jurnals Studia Islamika

Lembaga Penelitian dan Pengabdian Masyarakat (LP2M) IAIN Palu 
Jl. Diponegoro No. 23 Palu, Sulawesi Tengah 94221 Indonesia

Phone: +62-451-460798; Fax: +62-451-460165

E-mail: jurnalhunafa@yahoo.com; hunafajournal@gmail.com

Website: www.jurnalhunafa.org

HUNAFA

Jurnal Studia Islamika

\section{EDITOR-IN-CHIEF}

Nurdin, Institut Agama Islam Negeri Palu, Indonesia

\section{EDITORIAL BOARD}

Sagaf S. Pettalongi, Institut Agama Islam Negeri Palu, Indonesia

Rusli, Institut Agama Islam Negeri Palu, Indonesia

Tulus Suryanto, Universitas Islam Negeri Raden Intan Lampung, Indonesia

Ade Yeti Nuryantini, Universitas Islam Negeri Sunan Gunung Djati, Indonesia

Toto Suharto, Institut Agama Islam Negeri Sukoharjo, Indonesia

Reza Fahmi, Universitas Islam Negeri Imam Bonjol Padang, Indonesia

Mohamad Abdalla, University of South Australia, Australia

Cucuk Wawan Budiyanto, Universitas Sebelas Maret, Indonesia

Kevin W. Fogg, University of Oxford, United Kingdom

Al Makin, Universitas Islam Negeri Sunan Kalijaga Yogyakarta, Indonesia

Miftachul Huda, Universiti Teknologi Malaysia, Malaysia

Hendri Tanjung, Ibn Khaldun University Bogor, Indonesia

Muhammed Modassir Ali, Hamad bin Khalifa Universty, Qatar

Hamid Fahmi Zarkasyi, Universitas Darussalam Gontor, Indonesia 


\section{MANAGING EDITOR}

Mohammad Nur Ahsan, Institut Agama Islam Negeri Palu, Indonesia

\section{COVER DESIGN}

Lukman Latif 


\section{HUNAFA \\ Jurnal Studia Islamika}

\section{Contents}

Editorial

vi-vii

AL-KHAIRAAT POLITICAL KHARISMA

$1-18$

Syamsuri

BANGRENG AS A MEANS OF SPREADING ISLAM

Melyan Sofian, Cece Sobarna, Reiza D. Deinaputra, Deni Hermawan

FOREIGN LANGUAGE TEACHING AND INFORMATION COMMUNICATION TECHNOLOGY: IS THERE OPPORTUNITY FOR QURANIC LANGUAGE TEACHERS?

Nuril Mufidah, Abduganiy Abimbola Abdussalam, Aliy Abdulwahid Adebisi

IRAN REVOLUTION, ECONOMIC STRUGGLE AND INDEPENDENCE UNDER THE PRESSURE

Meirozon AlizarAli 
Umi Salamah

MAHRAM IMPLICATIONS IN WOMEN'S TRAVEL

$88-110$

Maulidah Tri Utami

MARKETING PERFORMANCE DETERMINANT

OF HALAL PRODUCTS IN INDONESIA:

Confirmatory Factor Analysis Approach

Aan Nasrullah

RELATIONS BETWEEN MOSQUE AND

$142-153$

SOCIAL HISTORY OF ISLAMIC EDUCATION

Anna Triayudha, Rateh Ninik Pramitasary, Hermansyah Akbar Anas, Choirul Mahfud 


\section{Editorial Preface}

Nurdin Nurdin, Institut Agama Islam Negeri (IAIN) Palu

This issue (Vol. 16 issues 1) of Hunafa: Jurnal Studia Islamika offers eight articles covering topics of Islamic studies. Various issues relating to Islamic studies are presented interestingly to contribute to the body of knowledge and practices. Academia and practitioners in Islamic studies may gain insight from reading these articles.

The first article is titled "Al-Khairaat Political Kharisma" by Syamsuri Syamsuri from Department of Dakwah, Faculty of Ushuluddin, Adab, and Dakwah, Institut Agama Islam Negeri Palu. This paper discusses the roles of Al-Khairaat in politics arena within local and national level. Several political parties have come to the Alkhairaat organization to recruit political cadres in the face of general election events.Alkahiraat's political charisma in the frame of political communication includes the participation, consolidation, and partnership of Alkhairaat politicians who spread in various political parties to win the election contestation.

The second article in the issue is titled "Bangreng as a Means of Spreading Islam" by Maylan Sofian, Cece Sobarna, Reiza D. Dienaputra, and Deni Hermawan from STKIP Sebelas April Sumedang. This paper describe Bangreng culture which was originally an example used by the Sumedang community as a medium to express gratitude for everything that Allah SWT gave to humans. But the function of art as a ritual began to shift into art as entertainment. This Bangreng art is an art that is very interesting to study because there are only a few different functions. This change does not change the name of the show. With this description, it needs to be isolated, that is, the community does not lose identity. The aim is that the public knows the function of the nation in the spread of Islam.

The third article is titled "Determinants of Halal Product Marketing Performance In Indonesia: Confirmatory Factor Analysis Approach" by Aan Nasrullah. This paper discussed the five variables that contribute to halal product marketing which are product competition, HR marketing performance, infrastructure, amount of distribution cost, and market competition.

The fourth article is titled "Foreign Language Teaching and Information Communication Technology: Is There Opportunity for Quranic Language Teachers?"by Nuril Mufidah, Abdulganiy Abimbola Abdussalam, Aliy Abdulwahid Adebisi from UIN Maulana Malik Ibrahim Malang and University of Ilorin, Ilorin, Nigeria. The article discuses the use of ICT in learning of Arabic. The subjects of the study were students of Arabic Language Education at UIN Maulana Malik Ibrahim Malang Indonesia 2018 academic year and students and Department of Arabic, Faculty of Arts University of Ilorin, Nigeria. The findings of the research are that ICT if adequately harnessed and utilized will go a long way in enhancing the quality of teaching of Arabic, as it was established to teaching other languages of the world.

The fifth article is by Meirizon Alizar Ali dari UIN Imam Bonjol. The article is titled "Iran Revolution, Economic Struggle and Independence under the Pressure" The article discusses 
Iran economy situation after experiencing various kinds of changes in economic policy and facing various kinds of situations Iran succeeded in developing the economy without changing the basics of Islamic shari'ah principles and revolution.

The sixth article is titled "Kaisa Method in Intelligence Multiple Perspective" by Umi Salamah from PGMI, STAI Ma'had 'Aly Al-Hikam, Malang. The article analyzed memorizing the Qur'an using the Kaisa method in the perspective of multiple intelligence. The Kaisa method is a way of memorizing the Qur'an which is oriented to memorization and understanding of the verses of the Qur'an along with their meanings through movements or kinesthetic which are adapted to the meaning of each verse so as to make it easy to understand and remember every verse of the Qur'an given.

The seventh article is titled "Mahram Implications in Women's Travel" by Maulidah Tri Utami from Faculty UshuluddinAdab and Humaniora, IAIN Salatiga. The article discusses mahram as well as a culture of the manner in which a woman is going out of her home or is drawn. From the various resources available this article determine when a woman can compete without mahram.that is how Islam respects and cares for a woman so much that it also notices when a woman is about to travel. Not just one woman, but all Muslim have a rule if a Muslim is to compete for a long time. So, when to reply a Muslim must meet or finish what he needs before taking a sauna.

The last article is titled "Relations Between Mosque And Social History of Islamic Education" by Choirul Mahfud Anna Triayudha, Rateh Ninik Pramitasary, and Hermansyah Akbar Anas from Institut Teknologi Sepuluh Nopember, Surabaya and Pascasarjana Universitas Muhammadiyah Sidoarjo. The article describe the early period of Islamic education, the Prophet provided exemplary by building and empowering mosques. The example of the Prophet continued with the Caliphs afterwards until the present era. The mosque was built by the Prophet from the Al Haram mosque located in Makkah, Quba Mosque located in Quba, Nabawi mosque located in Medina and so on. The role and function of the mosque at that time was as a place of prayer, a place of prayer, a place for discussion or deliberation, a meeting place to develop a war strategy and others related to the problems and needs of Muslims. From time to time, the role or function of the mosque has changed slightly. In essence, mosques are currently influencing the development of the social history of Islamic education in Indonesia.

I hope the articles presented in this issue add further empirical evidence to the growing body of research that examines various fields from Islam perspectives. The articles could trigger other research to study other field of study with Islam perspectives Islamic institutions in Indonesia.

Nurdin Nurdin

Editor-in-Chief

HUNAFA: Jurnal Studia Islamika

XVI, 1 


\title{
RELATIONS BETWEEN MOSQUE AND SOCIAL HISTORY OF ISLAMIC EDUCATION
}

\author{
Anna Triayudha ${ }^{1}$, Rateh Ninik Pramitasary ${ }^{2}$, and Hermansyah Akbar Anas ${ }^{3}$, and Choirul Mahfud ${ }^{4}$ \\ ${ }^{1}$ Pascasarjana Universitas Muhammadiyah Sidoarjo, Sidoarjo \\ ${ }^{2}$ Pascasarjana Universitas Muhammadiyah Sidoarjo, Sidoarjo \\ ${ }^{3}$ Pascasarjana Universitas Muhammadiyah Sidoarjo, Sidoarjo \\ ${ }^{4}$ Institut Teknologi Sepuluh Nopember, Surabaya, choirulmahfud@gmail.com
}

\begin{abstract}
The growth and development of Islamic Education is inseparable from the growth of institutions. The Prophet made it happen by establishing institutions that had a role in developing and advancing Islamic education, one of which was a mosque. Research on the relationship of mosques with the social history of Islamic education is discussed by using descriptive qualitative methods that are oriented to literature review. This paper shows that in the early period of Islamic education, the Prophet provided exemplary by building and empowering mosques. The example of the Prophet continued with the Caliphs afterwards until the present era. The mosque was built by the Prophet from the Al Haram mosque located in Makkah, Quba Mosque located in Quba, Nabawi mosque located in Medina and so on. The role and function of the mosque at that time was as a place of prayer, a place of prayer, a place for discussion or deliberation, a meeting place to develop a war strategy and others related to the problems and needs of Muslims. From time to time, the role or function of the mosque has changed slightly. In essence, mosques are currently influencing the development of the social history of Islamic education in Indonesia.
\end{abstract}

Keywords: Mosque, mosque function, and modernization

Abstrak. Pertumbuhan dan perkembangan Pendidikan Islam tidak lepas dari tumbuh kembangnya institusi. Rasulullah mewujudkannya dengan mendirikan pranata yang memiliki peran dalam mengembangkan dan memajukan pendidikan Islam, satu diantaranya adalah masjid. Penelitian mengenai hubungan masjid dengan sejarah sosial pendidikan Islam ini dibahas dengan menggunkan metode deskriptif kualitatif yang berorientasi pada kajian pustaka.Paper ini menunjukkan bahwa pada periode awal pendidikan Islam, Rasulullah memberikan keteladanan dengan membangun dan memberdayakan masjid. Keteladanan Rasulullah dilanjutkan para khalifah sesudahnya hingga era sekarang. Masjid yang dibangun olehRasulullah mulai masjid al Haram yang terletak di Makkah, Masjid Quba yang terletak di Quba, masjid Nabawi yang terletak di Madinah dan lain sebagainya. 
Peran dan fungsi masjid pada saat itu adalah sebagai tempat berdoa, tempat sholat, tempat berdiskusi atau musyawarah, tempat pertemuan menyusun strategi perang dan lainnya yang berhubungan dengan persoalan serta kebutuhan umat muslim. Dari masa ke masa, peran atau fungsi masjid sedikit terjadi perubahan. Pada intinya, masjid saat ini memberikan pengaruh dalam perkembangan sejarah sosial pendidikan Islam di Indonesia.

Kata kunci: Masjid, fungsi masjid, dan modernisasi

DOI: $10.24239 /$ jsi.v16i1.531.113-124

\section{Introduction}

The progress of the world of Islamic science is central and has an impact on the culture and culture of the Islamic community. The glory of Islam, also called the golden age, occurred in the eighth to fourteenth centuries. The range of this century is the glory of Islam in the scientific field. Morally and sociopolitically can be proven in the Caliphate of the Prophet who moved to advance knowledge in Medina. The glory of knowledge or science that is motivated by the context of the history of education in Islam is closely related to the growth and development of institutions. Educational institutions in Islam that contribute to science is a mosque. For Muslims in carrying out their worship activities, they cannot be separated from the mosque.

According to George Makdisi in The Rise of Collages conveying the sign that the institution that functioned for the initial learning or teaching activities of Islam was a mosque. ${ }^{1}$ The word mosque comes from the word Masjid following the phrase sajada, yasjudu which means worship, a place to bow down or align your feet and head. In this case, the mosque is a building or a fenced building, established for prayer, namely worshiping Allah SWT. The mosque is also called Baitullah (the house of Allah) so that everyone who enters this place is given a two raka'ah prayer called Tahiyatul masjid (respecting the mosque). Prophet

${ }^{1}$ George Makdisi, The Rise of Collages: Institutions of Learning in Islam and the West, Edinburgh: Edinburgh University Press: 1998, 21. 
Muhammad SAW said: "If one of your people enters the mosque, do not sit before doing the two rak'ah prayers" HR. Abu Dawud.

The mosque is one proof of the relics of Islam in the field of architecture. The origins of developing mosque construction cannot be separated from the growth of new cities and the struggle to expand the region. In the course of Islam which continues to expand to the corners of the country, if you come to a new place, then one of the places to go is a mosque. This sacred place is proof of manifesting Islamic art and is the most important culture. The mosque also describes the symbol and reflection of the love of Islam to Robb, namely Allah SWT. Mosque buildings that are amazingly beautiful in Spain, India, Syria, Cairo, Baghdad and a number of places in Africa are proof of the monumental heritage of Muslims who have experienced glory in the fields of technology, construction, art, and economics.

The most important war of the mosque was drawn from the leadership of the Prophet. When he emigrated from the city of Makkiyah to Madaniyah, the Prophet applied the construction of a mosque for the first concrete evidence for Muslim civilization. So, starting from that, mosque was made as the main navel point for Muslims. Therefore, the mosque is a reference for all forms of community and educational social activities for Muslim communities. ${ }^{2}$ All forms of activity are depicted as places of prayer or worship, as meditation, religious teaching, political discussion, and other activities both formal and informal. From the various activities, social activities grew which led to Islamic education because also the mosque was the heart or center of Islamic civilization.

All forms of activities lead to human meetings and the transfer of Islamic knowledge which ultimately plays an important role in the social history of Islamic education. At the beginning of the formation of a society with an Islamic background, a group of Muslim scholars had first used the mosque as a beneficial

${ }^{2}$ A. Halim Tamuri, "A New Approach in Islamic Educations: Mosque Based Teaching and Learning". Journal of Islamic and Arabic Education, 4, no. 1, (2012). 
activity of Islamic teaching. Submission of all education about Islam is carried out in mosques, including the education of war strategies in fighting for the existence of Islam. This is done to continue the struggle of the Prophet in spreading Islam. Based on the description above, it is important to know the function of the mosque and the position of the mosque during the initial period and the growth of Islamic education.

\section{Research Methods}

Theoretically, a qualitative research approach is research that starts with problems such as why, how, what, where, and when about a phenomenon or social symptoms that occur or are being observed by giving meaning to an event. Iskandar stated that a qualitative study that can either describe or explain, make interpretations, assess, validate and integrate the knowledge of the world and what applies in it. ${ }^{3}$ So, this study does not use quantitative because data obtained without calculation formulas, but descriptions ${ }^{4}$

This research is also based on literature review. Usually, this kind of research is also called the library research method which is research that obtains data by means of documentation. This method is done by collecting data from various traces of writing, for example authentic evidence in the form of archives, books on theory, or propositions related to research. ${ }^{5}$ The nature of this research method is descriptive, which is a method that exposes information without being added or reduced, so that it matches the indicators of the problem under study and is not related to numbers or formulas as in quantitative methods. ${ }^{6}$

\section{Discussion}

The understanding of ordinary people that the use of the mosque is to carry out five daily prayers, Friday prayers, tarawih, the commemoration of

${ }^{3}$ Iskandar, Metodologi Penelitian Pendidikan dan Sosial. (Jakarta: Referensi, 2013).

4J. Moleong. Metodologi Penelitian Kualitatif. (Bandung: Remaja Karya, 1989).

sIbid.

${ }^{6}$ Mardalis. Metode Penelitian, (Jakarta: Bumi Aksara, 1995). 
Islamic days and only related to human relations with Allah SWT. The manifestation of the construction of the mosque is a proof of Muslim love for Allah SWT. This building is also a manifestation of the development and progress of Islamic civilization. This institution is the work of Muslim culture in the field of construction to continue the example of the Prophet SAW. There are various functions of the mosque that can be seen from its history. The actual function of the mosque can be referred to the history of the earliest mosques, namely the use of mosques in the time of the Prophet Muhammad, al Kulafa'ar-Rasyidin, and so on. At that time, the mosque had two functions, namely religious functions and social teaching. The function of the mosque is not focused on prayer activities only. The existence of this institution also provides a place for Islamic worshipers to strengthen ties and relationships in the process of obtaining teaching. This is so that social humanity is built without seeing junior or senior worshipers because Islam teaches balance. The Prophet Muhammad when functioning the mosque was not only a place of worship, but also to convey the revelations he had obtained. Delivering da'wah, giving fatwa to his friends and the entire Islamic community. He also teaches deliberation, gives solutions to problems or problems faced, composes war strategies, answers all questions of the companions of the Prophet and places to get all messengers from the Arabian Peninsula.

Closely related to social action in education, the Nabawi mosque was the first to be a tangible evidence. This is what inspired the emergence of many mosques in the current era. ${ }^{7}$ In this place there is a room called suffah, which is to support the needy. Nabawi Mosque is also used for resting all Muslims who intend to explore Islam. At the Abbasid era, the mosque served as a place for scientific meetings for scholars. Mosques have a role in developing Islamic science and culture. The Village Area in Indonesia is the highest percentage that is striking in the application of places of worship. Here, the mosque functioned as it should according to the teachings of the Prophet. Nearly the existence of mosques in the 
village has never been quiet from the people. Many activities are carried out, namely reading the Qur'an, studying religion, and commemorating Islamic holidays. In the village, without having to be coded, people flocked to pray in congregation to the mosque. This seems different with the city. Observation of results in the field, even though it is carrying out the same function, the reality is not the same. Mosques in the city will only be crowded if there are many visitors who stop-by because the surrounding communities are mostly individuals who prefer to worship in their homes. The routine of reciting the Qur'an taught to children is rarely found. So, the film Masjid Yang Tak Dirindukan(The Not Missed Mosque) is a manifestation of the existence of mosques in urban areas.

Since it was built by the Messenger of Allah, the components or parts of the mosque include the tower, dome, mihrab, pulpit, and place of ablution. This component has its own uses. Its usefulness is clearly illustrated by the history of the mosque itself. Where, the Messenger of Allah established a mosque for learning, transferred the revelations obtained, the place of deliberation (both problem solving, preparation of war tactics and conveying ideas), as a resting place even caring for sick people. The mosque's components are not just sweeteners or to show beauty. The tower is the tallest building as a sign for the people to know the existence of the mosque. In the present era, this building has added speakers or loudspeakers for adhan and other announcements. Mihrab is a place for priests or prayer leaders in carrying out their duties to lead Muslim worshipers. The location of the mihrab usually slides into the front of the room. Mihrab is also called the core of the mosque. The Mihrab couple is the pulpit. If Mihrab is in the form of a room that has been pushed inward, then the pulpit is a place made of wood that can be moved, in this era, the pulpit is made of stainless steel, a harboard, even glass. This is because the world is increasingly modern. The function of the pulpit is a place for priests when preaching. Last is the place of ablution. The place of ablution is a component of the mosque which is provided to purify oneself before performing the prayer or just reading the Qur'an. 
At first, the development of education in Islam occurred when the Prophet began to lead, through the teachings of Islam that had been exemplified. At first, the practice of Islamic education was carried out in a simple but meaningful manner. In practicing Islamic teachings, the Prophet applied the exemplary method. This method is very powerful in answering all problems in contemporary education. ${ }^{8}$ There is even the expression that one example is better than 1000 advices. This shows that the method of equality is the key to success in Islamic education. One of the Prophet's example was the construction of a mosque that had an important and strategic role both when in Makkah or Madinah. In Makkah, al Haram is a mosque that is a place to transfer revelations from Allah openly, triggering a response and crackdown from the Quraish polytheists as experienced by Abdullah ibn Mas'ud. This also happened when the Messenger of Allah arrived at Quba in his destination to Yastrib.

He carried out his vision to establish a mosque which is known as the Quba Mosque for four days. Quba Mosque is the mosque that was first established by the Prophet on the $13^{\text {th }}$ year of his preaching or the $1^{\text {st }}$ year of hijriyah, precisely 28th June $622 \mathrm{AD}$. It was the first construction as well as a basic model for Muslims in building mosques afterwards. The side of the Quba Mosque is used as the main point of worship. Not only that, this side also teaches Islamic education. Therefore, Mu'adz ibn Jabal is positioned by the Prophet as a prayer leader and teacher who teaches religion in this mosque. So, in performing their prayers at the Quba mosque, the Prophet traveled by riding a Camel or even on foot.

The Prophet's journey finally arrived at Yastrib after 4 days in Quba building the Quba Mosque, this was done at Yastrib. The Prophet built a simple mosque with land as its floor, the walls were also made of soil through the drying process. Making poles made from sticks and palm trees, and the roof comes from the fronds of the fruit leaves. Based on history, the size ranges from $35 \times 30 \mathrm{~m}^{2}$. The Prophet called it the Nabawi Mosque even though it was in Quba. On the

${ }^{8}$ Choirul Mahfud, Politik Pendidikan Islam. (Yogyakarta: Pustaka Pelajar, 2016). 
eastern side of Nabawi, there is a simple residence for the Prophet. To the west, a room was made for the poor followers of the Prophet. This people is known as the word Muhajirin or the term al shuffah. The explanation of the Quraish Sihab that the Nabawi mosque had a significant function, that is, directly the Prophet leads in empowering mosques as a place to shape social life more ideally. These ideals are realized through civil society. The spirit of the struggle of the Prophet and his companions did not stop here, he continued to promote development and pay attention to the care of other mosques. In addition to the two buildings above, the Prophet and his companions also founded and paid attention to the care of other mosques. The construction and maintenance for example is the establishment of the Qiblatin, Fadikh, Afr, Bani Quraizah and Al-Aqsa Mosques. The al Aqso worship institution is the second mosque after al-Haram in Mecca and dubbed as the oldest mosque.

The example of the Prophet in empowering the mosque was finally passed on by the leaders after the Prophet. This is clearly illustrated by the leadership of Khulafa al-Rashidin which also established a mosque in his territory. At the time of Umar ibn Khattab built a mosque known as the Umar Mosque where the founding process was located on a hill named Muriah. This mosque is circular, the walls are made of clay and without a roof. Not only the Caliph but the leader of the war forces also continued the example of the Prophet in the construction of the mosque. For example, Sa'ad ibn Abi Waqqash, who at that time served as warlord, also took action to build a mosque by utilizing the use of materials from Hiroh. These materials come from old Persia. This event occurred in 17 Hijriyah in the Khufah region and could be completed in the next period, 18 Hijriyah. The physical mosque built by Sa'ad has a beautiful mihrob and tower.

The fact that occurred in the present or modern era or known as the millennial century regarding the existence of the role or function of the mosque in the social history of Islamic education has undergone changes and social 
dynamics. ${ }^{9}$ In fact, the role of the mosque of the present era is increasingly eroded. This was triggered by the weakening of officials in each mosque in inviting the millennial generation to love their places of worship. Obviously illustrated, the function of the mosque of the present era is only treated as a sanctified place of all things which pollute either in deeds or in words, both physically and mentally. Even today mosques seem to make it difficult for someone who wants to take up worship to meet Allah.

Based on the soap opera "Masjid Yang Tak Dirindukan" (The Missed Mosque) which aired on ANTV has clearly illustrated the existence of millennial mosques. The story described is much found in everyday life. Lazy people go to mosques for various reasons. Neglect in mosque care and so on. Events in the field explained, in some areas the sanctified place was too excessive, that poor people dressed in slums were forbidden to set foot. In fact, for them it was indeed the best dress and for them it was neat and clean. Another thing happened, the treatment was due to organizational differences and even the friction between organizations. If you look at the early days of the history of Islamic education, the example given by the Prophet on building a mosque was to strengthen the fellowship of fellow Muslims and even non-Muslims. ${ }^{10}$ Because in the era of the Prophet Muhammad mosques are functions, to pray, to teach the science of religion which is now known as $\mathrm{TPQ}$, for deliberation, composing war strategies and so forth. In fact, all the examples of the Prophet do not fit the role of the mosque today.

Quoting various news on radio, newspapers, and television, mosques which are considered sacred are actually becoming immoral places or percussion events. The mosque should be a positive place, but it was tarnished because of humans whose mindsets were insane. The doerdoes not all come from gangster

${ }^{9}$ Biyanto, "The typology of Muhammadiyah Sufism: Tracing its Figures' Thoughts and Exemplary Lives", Indonesian Journal of Islam and Muslim Societies, 7 no. 2, (2017): 221-249.

${ }^{10}$ Syamsul Arifin, Studi Agama: Perspektif Sosiologis Dan Isu-Isu Kontemporer, (Malang: UMM Press, 2009). Muhammad Ayub, dkk.,Manajemen Masjid, (Jakarta: Gema Insani Press, 1996.) 
background but many of them are teenagers of the mosque themselves whose common sense cannot work well.

Reading from bad events, the existence of mosques should be in line with the advancement of the era, making generations to use it better. If it is related to the habits of today's young people, mosques should be a favorite place. To realize this, the consciousness of the generations must be awakened. The administrators in any mosque should not be bored to always be active in inviting and encouraging the current generation. ${ }^{11}$ The influence of the mosque administrator is very important. In the village, it usually starts from the community leaders to give a good example that is not only loving, but also always misses the mosque.

The effort to make generations have love and longing is to create comfort. Millennial children love the relaxed atmosphere that is neither stiff nor monotonous. Thus, this solution can be developed to make mosques as comfortable discussion posts, favored by generations like coffee shops, but without changing the rules of religion. If, this solution is successfully implemented, mosque administrators never give up or passively, most likely all will be in accordance with millennial generations' preferences. With this, the mosque will be a place for pleasant discussion, a brilliant idea poured out, a millennium that is more productive in terms of goodness, of course. All this is done so that mosques today are not only beautiful from the construction of the building but also provide more useful roles in Islamic teaching and education.

\section{Conclusion}

Based on the explanation above, regarding the relationship between mosques and the social history of Islamic education which explains the use of mosques, the existence of mosques in the history of Islamic education cannot be separated from continuing the example of the Prophet. The social characteristics are well exemplified which set an example for leaders after Rasulullah, warlords

${ }^{11}$ Syahidin, Manajemen Masjid: Suatu Pendekatan Teoritis dan Organisatoris, (Yogyakarta: PT Dana Bakti Prima Yasa, 2004). 
and even the present era who did not escape the development and empowerment of mosques.

Many social activities that lead to Islamic education that are related to the problems of Muslims, become places of worship, places of discussion or deliberation, places to share knowledge of religion, and others. However, the mosque of the present era can no longer be expected to only be a function of mosques in the early period of Islam. This is reflected in the current trend mosque which is only treated in a disciplined manner as a home for Allah who must be pure or guarded from any matter. This anticipation can avoid things that can pollute both inner and outer, both in deeds and words. In some other areas, the mosque was even treated as a place that made it difficult for servants who wanted to meet their Lord. This is due to organizational differences or even friction between organizations and limited social status, because nowadays many mosques are built independently by individuals and groups of organizations.

Listening to various news related to the weakening role of the mosque, the influence of the board was greatly needed. Through mosque administrators, awareness of the millennial generation can be encouraged. With ceaselessness without boredom, fostering a sense of love even longing for a mosque. So, the mosque is not only a place of prayer but also for all positive activities or even the most hits hangout. Not to do evil or even immoral acts which ultimately lead to a bad image, especially the opinions of other beliefs about Muslim places of worship.

\section{References}

Amin, Samsul Munir.,Sejarah Peradaban Islam, Jakarta: Amzah, 2009.

Arifin, Syamsul, Studi Agama: Perspektif Sosiologis Dan Isu-Isu Kontemporer, Malang: UMM Press, 2009.

Ayub, Muhammad.,dkk., Manajemen Masjid, Jakarta: Gema Insani Press, 1996.

Biyanto, "The Typology of Muhammadiyah Sufism: Tracing its Figures' Thoughts and Exemplary Lives", Indonesian Journal of Islam and Muslim Societies 7 (2), 2017: 221-249. 
Faruq, Asadulloh Al., Panduan Lengkap Mengelola dan Memakmurkan Masjid, Solo: Pustaka Arafah, 2010.

Gazalba, Sidi.,Masjid Pusat Ibadah dan Kebudayaan Islam, Jakarta: Pustaka Al-Husna, 1994.

Heriyanto, Husain. Mengenai Nalar Saintifik Peradaban Islam. Bandung: Mizan, 2011.

Iskandar, Metodologi Penelitian Pendidikan dan Sosial. Jakarta: Referensi, 2013.

Mahfud, C., "The Role of Cheng Ho Mosque: The New Silk Road, Indonesia-China Relations in Islamic Cultural Identity", Journal of Indonesian Islam 8 (1), 2014: 23-38.

Mahfud, Choirul. Politik Pendidikan Islam. Yogyakarta: Pustaka Pelajar, 2016.

Makdisi, George The Rise of Collages: Institutions of Learning in Islam and the West, Edinburgh: Edinburgh University Press: 1998, 21.

Mardalis. Metode Penelitian, Jakarta: Bumi Aksara, 1995.

Moleong, J. Metodologi Penelitian Kualitatif. Bandung: Remaja Karya, 1989.

Nizar, Samsul, Sejarah Pendidikan Islam, Jakarta: Kencana, 2007.

Syahidin, Manajemen Masjid: Suatu Pendekatan Teoritis dan Organisatoris, Yogyakarta: PT Dana Bakti Prima Yasa, 2004.

Tamuri, A. Halim, “A New Approach in Islamic Educations: Mosque Based Teaching and Learning." Journal of Islamic and Arabic Education 4 (1), 2012. 